
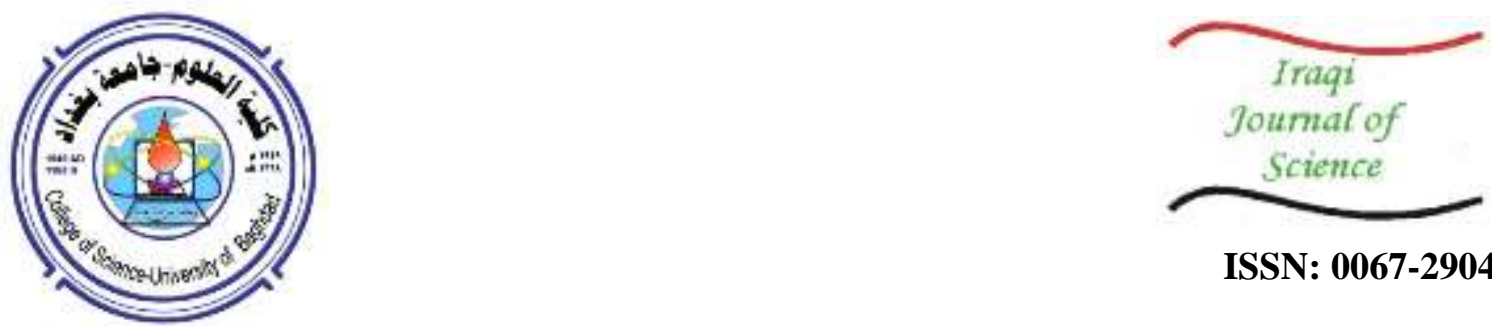

ISSN: 0067-2904

\title{
Hydrochemistry of Tigris River in Baghdad city, Iraq
}

\author{
Haneen Zaid Abdulazeez ${ }^{1 *}$, Ayser Mohammed Al-Shamma'a ${ }^{1}$, Qays Jasim Saud ${ }^{2}$ \\ ${ }^{1}$ Department of Geology, College of Science, University of Baghdad, Baghdad, Iraq \\ ${ }^{2}$ Ministry of industry and minerals, Iraq Geological Survey
}

Received: 4/12/2019 Accepted: 12/4/2020

\begin{abstract}
The main objective of this study was to investigate the current water-quality conditions in Tigris River, Baghdad, Iraq, and to determine how those conditions are changing over time of pollution, if any. A series of hydrochemical tests were carried out to ascertain the influence of major Cations and Anions, Total Dissolved Solids (TDS), Electrical Conductivity (EC) and Potential of hydrogen (pH) on the quality of water. Water samples $(n=34)$ were collected along Tigris River from north to south Baghdad City; 17 on January 2019 and 17 on April 2019. The results of the tests were compared with the World Health Organization standards, and showed that all the ions in addition to EC and TDS are within the acceptable limits, except for the samples 7 and 16 where Sulfate concentration was above the acceptable limits. Therefore, the Tigris River water in most of the study area is acceptable for all kinds of consumption. The most common water type in the area was $\mathrm{Ca} \mathrm{Na} \mathrm{Mg}-\mathrm{SO}_{4} \mathrm{Cl}$ $\mathrm{HCO}_{3}$ in January 2019 and $\mathrm{Na} \mathrm{Ca} \mathrm{Mg-} \mathrm{SO}_{4} \mathrm{Cl}$ in April 2019.
\end{abstract}

Keywords: Hydrochemistry- Baghdad- pollution- Tigris
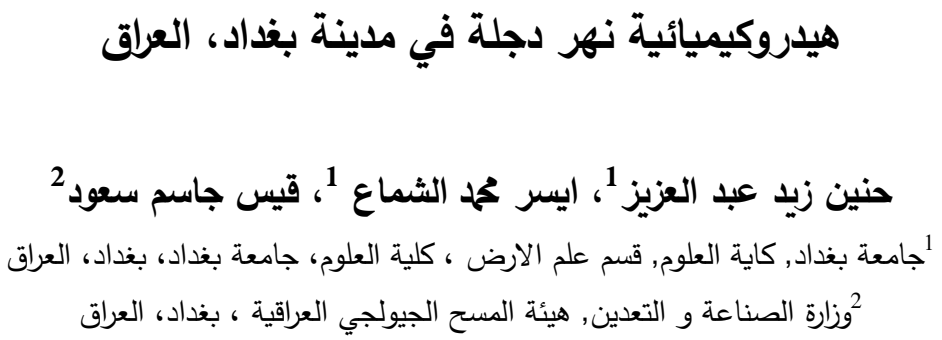

الخلاصه

ان الهدف الأساسي من هذه الدراسة هو تقييم نوعية المياه في نهر دجلة في مدينة بغداد، العراق وتحديد

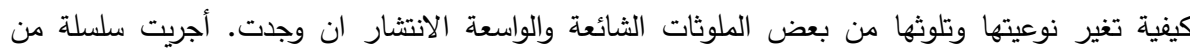

الفحوصات المختبرية لمعرفة تأثير تراكيز الايونات الموجبة والسالبة، و مجموع الاملاح الذائبة و التوصيلية

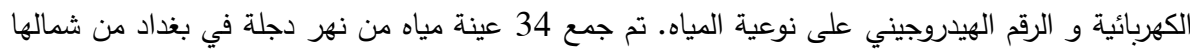

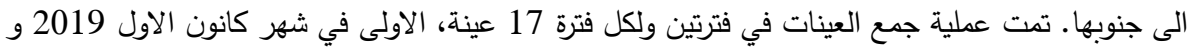

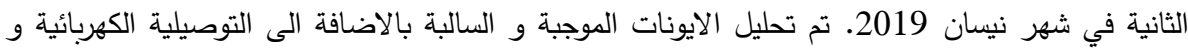

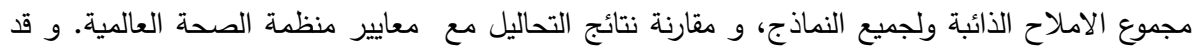

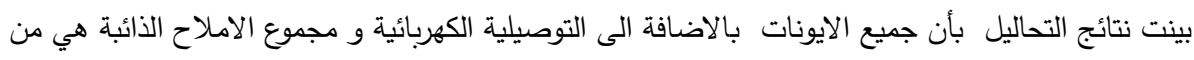

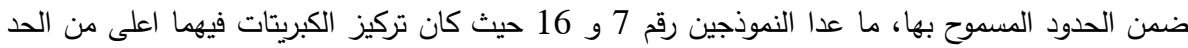

*Email: alhaidaryhaneen@gmail.com 


$$
\begin{aligned}
& \text { المسموح به، و لهذا فأن الماء في معظم منطقة الدراسة صالح للشرب. تصنيف و نوع المياه الاكثر شيوعا في }
\end{aligned}
$$

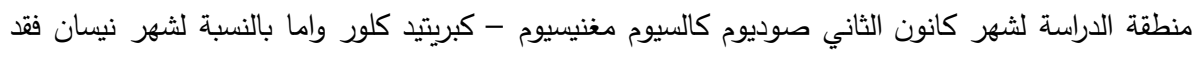

$$
\begin{aligned}
& \text { كان التصنيف صوديوم مغنيسيوم - كبريتيد كلور الكربونات الثائية. }
\end{aligned}
$$

\section{Introduction}

In Iraq, Tigris River and its tributaries are valuable resources that provide water necessary for drinking for an increasing population, crops irrigation, and habitats for aquatic life, in addition to its remarkable recreational opportunities .

Tigris, along with Euphrates, makes up a river system that borders Mesopotamia in the area known as the Fertile Crescent. According to National Geographic, The Tigris River is one of the most important waterways in the Fertile Crescent and has supported cities in both Turkey and Iraq, including Hasankeyf, Mosul, and Baghdad, for centuries [1].

Tigris length is about $1800 \mathrm{~km}$, of which about $400 \mathrm{~km}$ run through Turkey before entering Syria then Iraq. The total length of Tigris in Iraq is about $1418 \mathrm{~km}$, which is more than three quarters of the total length, with $60 \mathrm{~km}$ in Baghdad. Yet, pollution from urban and agricultural areas continues to pose a threat to Iraq water quality. According to Briggs, many environmental changes have been occurring globally at rates that were never experienced before in our planet's recent history [2]. Since 1980, Iraq and its people have extremely suffered as a result of the continuing wars that have led to the almost total destruction of its infrastructure. This includes the destruction of oil refineries in addition to the burning of large numbers of oil wells along with leaking that constantly happens in oil pipelines which transfer crude oil and its derivatives (Figures-(1\&2). In addition, water treatment plants have been destroyed in most of Iraq's cities, including Baghdad. As a result, millions of liters of sewage are directly discharged without any treatment to the rivers and their tributaries or groundwater reservoirs. Not only that, but also most of the sewage outlets of many service institutions, such as hospitals, power plants, oil refineries and others, which are located on the shoulders of rivers, have been discharging all their solid and liquid waste directly into the rivers, including the Tigris. Another factor is the recent flooding that washed pollutants from soil into rivers (Figure-3). As a result of all of the above, the Iraqi environment in general suffers from pollution that causes high risks both to the environment itself and to its inhabiting forms of life. The quality of water depends on the dissolved ions or other contaminants occurring in the water. Thus, this study attempts to evaluate the environmental pollution in the study area by collecting water samples from Tigris River in Baghdad and analyze them in the laboratories to detect any contamination. The study results presented here may assist in understanding the potential influence of the contaminants on designing a more cost-effective remediation plan for contaminated water. Some of the previous studies conducted on this area include a hydrogeological environmental assessment study by Ali [3], of the effects of Al- Rasheed electrical power plant on the quality of Tigris River, Southern of Baghdad using Canadian Water Quality Index (CCME WQI) byAlazawii, et al. [4], and assessment of magnetite polishing using Tigris River stream sediments in Baghdad by Awadh and Khalid[5]. 


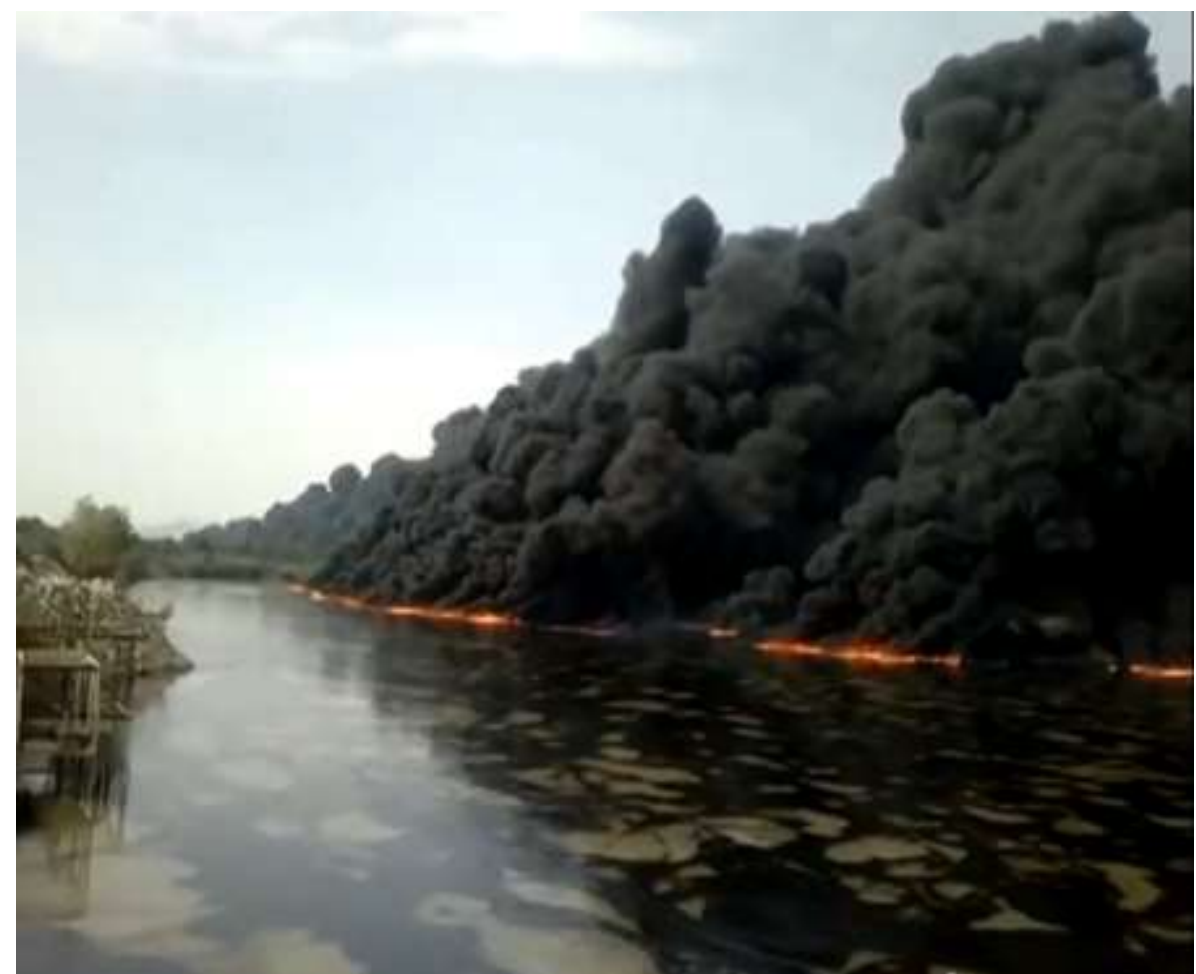

Figure 1-Tigris River, Baiji City, Iraq.
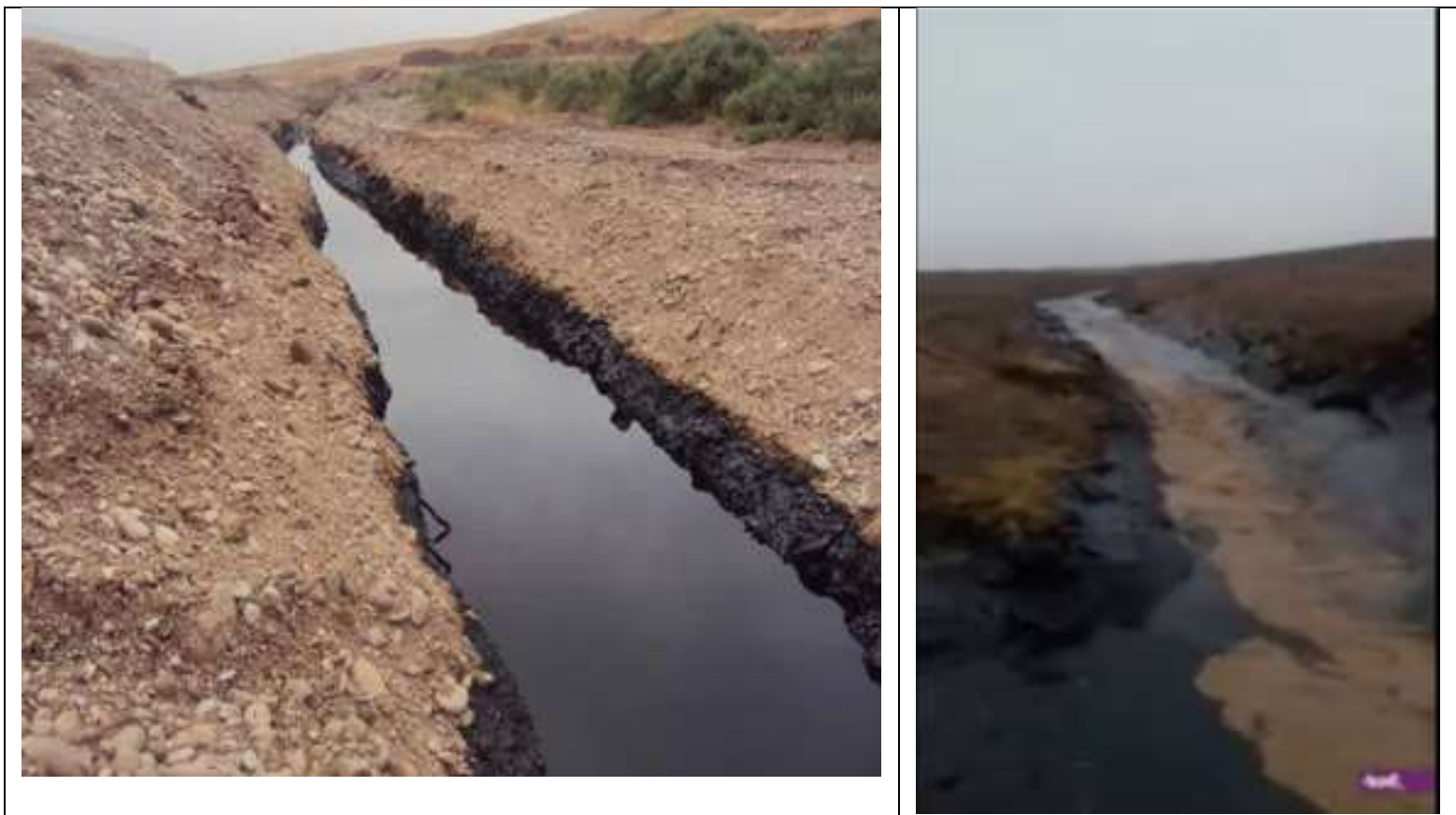

A: Apr 17, 2014

B: October 6, 2018

Figure 2-Dug channel used to smuggle crude oil from Allas oil field, Tikrit Governorate [6] 


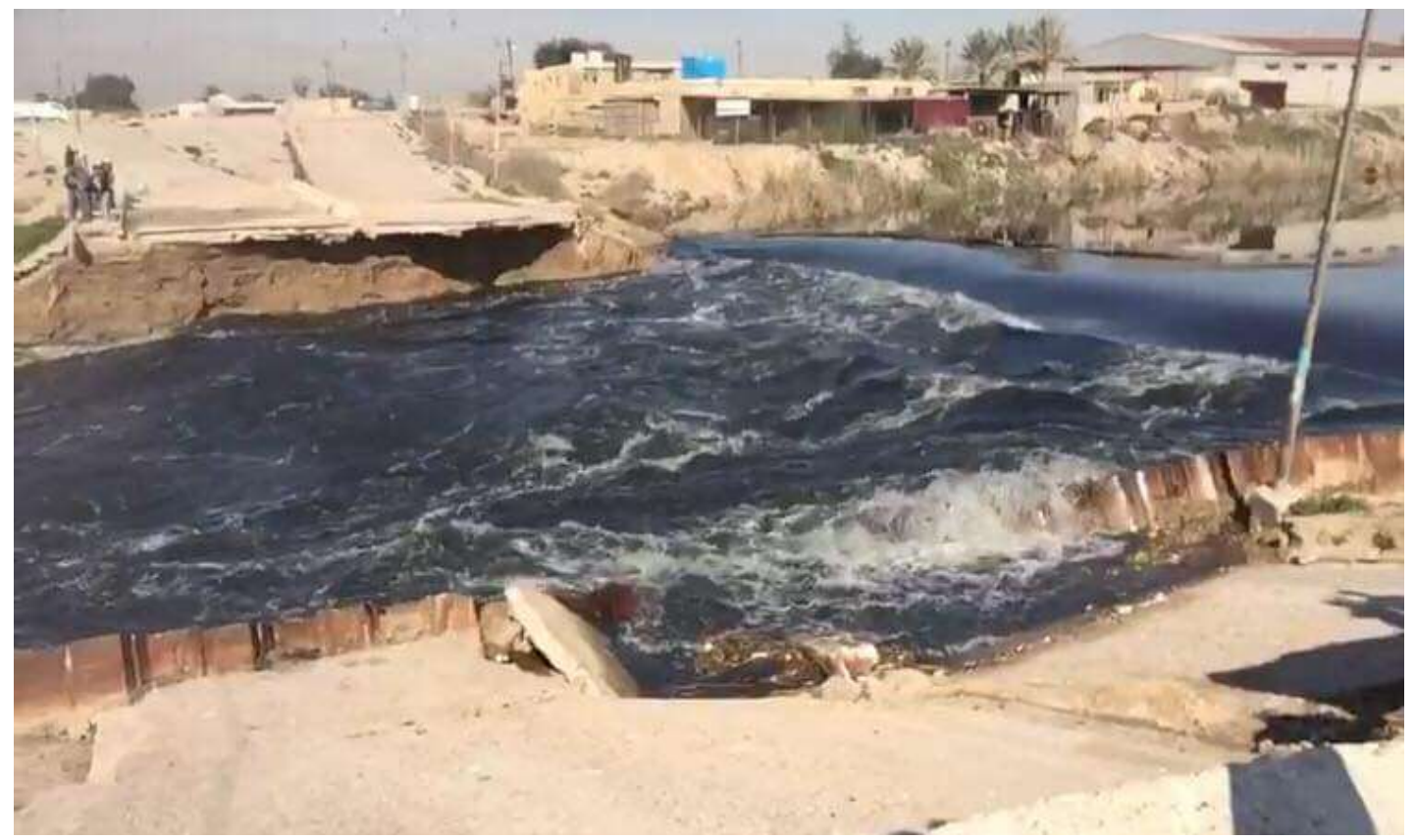

Figure 3-Flooding in Dyala River, Dyala City, Iraq

The main aim of this study is to evaluate the water quality in Tigris River in Baghdad, where many facilities discharge waste directly into the river.

\section{Location of the study area}

Baghdad is the capital and the largest city in Iraq, the second largest city in the Arab world after the capital of Egypt, Cairo, and the second largest city in Western Asia, after Tehran city, Iran. According to Encyclopedia Britannica Online, the area of Baghdad is $204.2 \mathrm{~km}^{2}$ and its population is more than 8 million which, however, is not based on official records [7]. The Tigris River passes from the middle of Baghdad, where the western side of the river is called Al Karkh area, while the eastern side is $\mathrm{Al}$ Rusafa. Moreover, Baghdad was the largest city of the middle Ages for much of the Abbasid era, peaking at a population of more than a million [8]. The study area covers 17 sampling stations along Tigris River flowing through Baghdad, within the following geographical coordinates: Longitude: 44॰18'10.455"- 44॰34'08.857"E and Latitude: 33॰27'46.232"- 33॰08'18.225"N (Figure-4). 


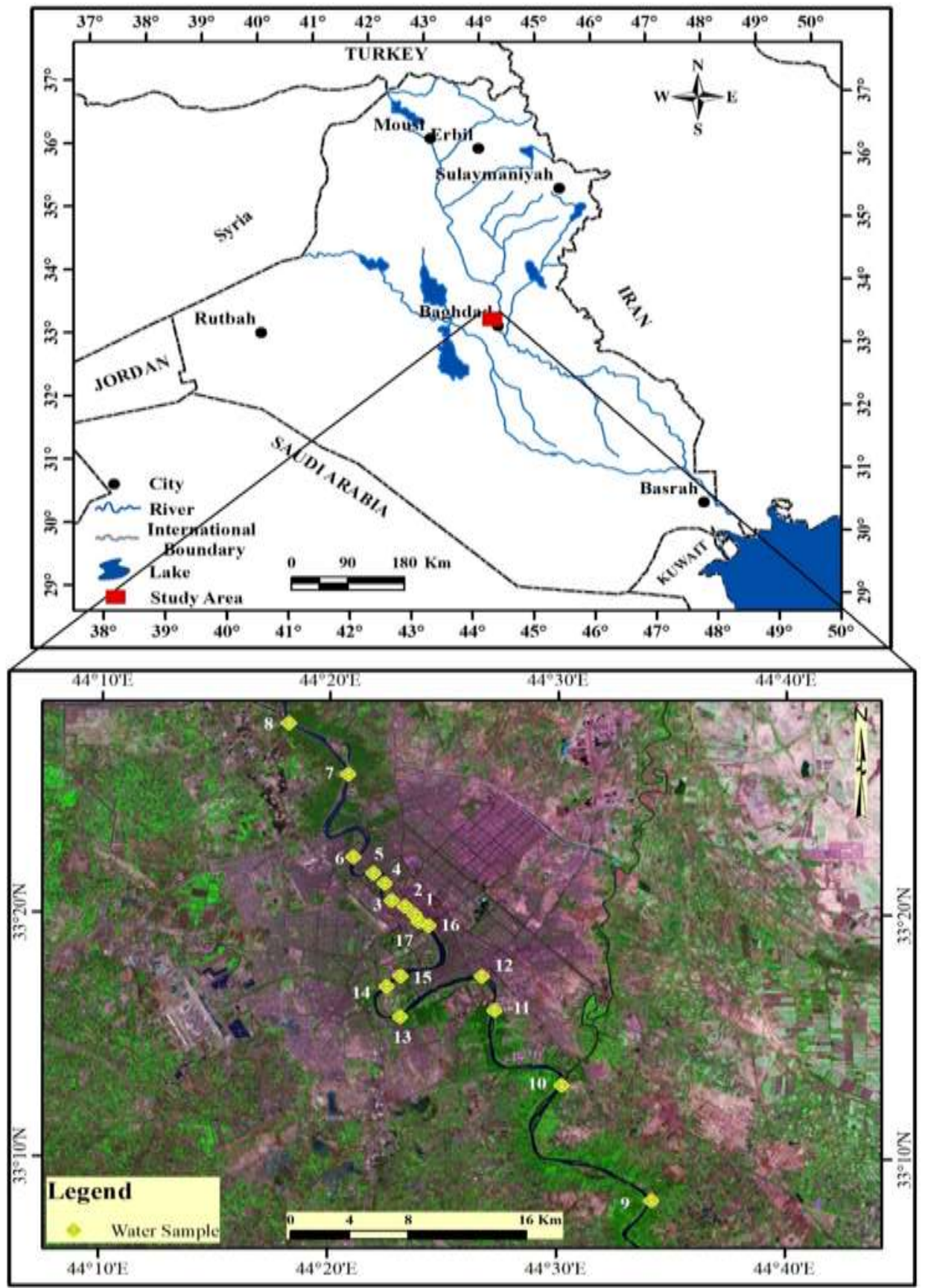

Figure 4- Location of the study area.

Table 1- Location of the collected samples

\begin{tabular}{|c|c|c|c|}
\hline \multirow{2}{*}{ Station No. } & Site names & \multicolumn{2}{|c|}{ Coordinates } \\
\cline { 2 - 4 } & N & E \\
\hline $\mathbf{1}$ & Al- Ahrar bridge & $33^{\circ} 19^{\prime} 58.148^{\prime \prime}$ & $44^{\circ} 23^{\prime} 45.333^{\prime \prime}$ \\
\hline $\mathbf{2}$ & Al-Shuhada'a bridge & $33^{\circ} 20^{\prime} 17.99^{\prime \prime}$ & $44^{\circ} 23^{\prime} 18.474^{\prime \prime}$ \\
\hline $\mathbf{3}$ & Bab AL-Muazm bridge & $33^{\circ} 20^{\prime} 32.416^{\prime \prime}$ & $44^{\circ} 22^{\prime} 44.252^{\prime \prime}$ \\
\hline
\end{tabular}




\begin{tabular}{|c|c|c|c|}
\hline $\mathbf{4}$ & Al-Sarafia bridge & $33 \circ 21^{\prime} 13.797^{\prime \prime}$ & $44 \circ 22^{\prime} 25.312^{\prime \prime}$ \\
\hline $\mathbf{5}$ & AL-A'azamia bridge & $33 \circ 21^{\prime} 39.286^{\prime \prime}$ & $44 \circ 21^{\prime} 54.955^{\prime \prime}$ \\
\hline $\mathbf{6}$ & Al-A'ema bridge & $33 \circ 22^{\prime} 19.363^{\prime \prime}$ & $44 \circ 21^{\prime} 02.245^{\prime \prime}$ \\
\hline $\mathbf{7}$ & Al- Muthana bridge & $33 \circ 25^{\prime} 42.286^{\prime \prime}$ & $44 \circ 20^{\prime} 47.481^{\prime \prime}$ \\
\hline $\mathbf{8}$ & Tigris arm canal & $33 \circ 27^{\prime} 46.232^{\prime \prime}$ & $44 \circ 18^{\prime} 10.455^{\prime \prime}$ \\
\hline $\mathbf{9}$ & Salman pack & $33 \circ 08^{\prime} 18.225^{\prime \prime}$ & $44 \circ 34^{\prime} 08.857^{\prime \prime}$ \\
\hline $\mathbf{1 0}$ & Al - Tuaetha & $33^{\circ} 13^{\prime} 00.00^{\prime \prime}$ & $44 \circ 30^{\prime} 12.579^{\prime \prime}$ \\
\hline $\mathbf{1 1}$ & Al- saeeda & $33 \circ 16^{\prime} 03.322^{\prime \prime}$ & $44 \circ 27^{\prime} 16.484^{\prime \prime}$ \\
\hline $\mathbf{1 2}$ & Al-Rasheed oil station & $33 \circ 17^{\prime} 26.556^{\prime \prime}$ & $44 \circ 26^{\prime} 42.745^{\prime \prime}$ \\
\hline $\mathbf{1 3}$ & AL- Dora electricity station & $33 \circ 15^{\prime} 46.413^{\prime \prime}$ & $44 \circ 23^{\prime} 07.376^{\prime \prime}$ \\
\hline $\mathbf{1 4}$ & AL- Jadyrea bridge & $33 \circ 17^{\prime} 00.619^{\prime \prime}$ & $44 \circ 22^{\prime} 31.913^{\prime \prime}$ \\
\hline $\mathbf{1 5}$ & Suspended bridge & $33 \circ 17^{\prime} 27.026^{\prime \prime}$ & $44 \circ 23^{\prime} 0.8147^{\prime \prime}$ \\
\hline $\mathbf{1 6}$ & AL- Jumhuria bridge & $33 \circ 19^{\prime} 31.874^{\prime \prime}$ & $44 \circ 24{ }^{\prime} 21.277^{\prime \prime}$ \\
\hline $\mathbf{1 7}$ & AL- Senk bridge & $33 \circ 19^{\prime} 41.297^{\prime \prime}$ & $44 \circ 23^{\prime} 55.902^{\prime \prime}$ \\
\hline
\end{tabular}

\section{Geological setting}

According to Jassim and Goff, the study area lies within the Stable shelf in the Mesopotamian zone, which contains the Tigris River and is covered with Quaternary sediments which overlie a complete Mesozoic and Cenozoic section [9]. The Quaternary sediments include Pleistocene and Holocene sediments. Geologic formations that crop out in the study area are the Pleistocene sediments which comprise Al-Fat'ha alluvial fan sediments, terrace of Euphrates River, gypcrete, and old flood plain sediments, as shown in Figure-5. The Holocene sediments comprise the flood plain; valley and depression fill sediments, marsh sediments, aeolian sediments and Anthropogene sediments (according to Deikran and Yacoub). The Fat'ha (Lower Fars) Formation is of the Middle Miocene age; its lower part is composed of alternating thick greenish and reddish silty claystone with layers of thinly bedded limestone and grayish sandstone. The upper part is composed of alternating beds of anhydrite, gypsum and salt, inter-bedded with limestone, marl, and relatively fine grained clastic, as shown in Figure-5. Gypcrete (Pleistocene) is intensively developed in the area between the Euphrates River and AlRazzaza Lake, covering the sediments of Injana Formation and the remnants of the terrace sediments. Gypcrete, in the map, has a thickness range of $0.5-2 \mathrm{~m}$. Undifferentiated Pleistocene Sediments, boreholes that penetrated the fluvial sediments below the flood plain sediments in the Mesopotamia Plain, are of the Pleistocene age and stratigraphically equivalent to the exposed Euphrates terrace sediments and alluvial fan sediments of the Tigris River. These fluvial sediments consist mainly of sand, pebbly sand and sandy gravels. The gravels gradually decrease east and southeastwards, towards the axis of the quaternary fluvial basin, with a total thickness of about $30 \mathrm{~m}$ in the area between Tigris and river. However, the thickness is expected to be greater further towards off the basin [10]. 
According to Deikran and Yacoub, the Flood plain sediments represent the most extensive sediments in the map area, which are the main Holocene sedimentary cycle of the Mesopotamia basin. Three rivers, namely Euphrates, Tigris, and Diyala-partly from Al-Udhaim River- were mainly the source of deposition of the flood plain. Each river develops district flood plain starting from the river channel, through natural levee to the flood basin. These morphologic elements of the flood plain have deposited with characteristic sedimentary facies. They differ from each other by grain size distribution and sedimentary structures. The valley filling sediments are mainly concentrated on the alluvial fan and terrace sediments, whereas in the Mesopotamia flood plain district, they are rare. The valleys are generally wide and shallow; some of them pass to wide depression. They are filled by fine Clastic rocks where clayey silt, silty-clay, and mud are dominating, with few admixtures of fine pebbles and rock fragments that contain very fine gypsum grains or powdered gypsum. Also, they are contaminated by windblown materials. Marsh sediments are developed in some depressions, which are characterized by distinct organic mud horizon with dark grey or black color, deposited to soil, indicating dense humiliated plants [11].

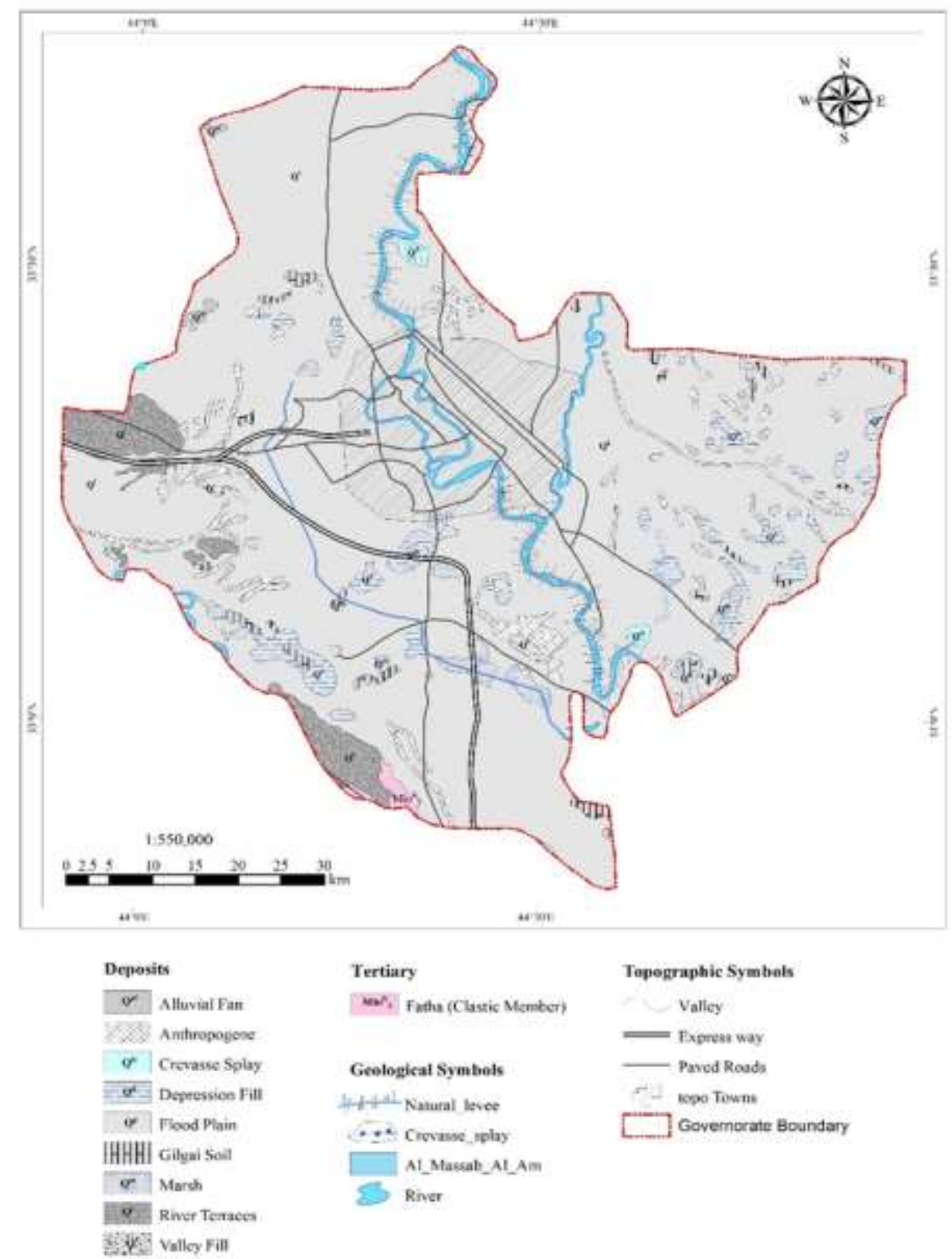

Figure 5-Geological map of Baghdad [11]. 


\section{Materials and methods}

Preliminary office work included gathering all available related literatures, theses, and researches that correspond with geology, hydrology and hydrogeological information of the study area. Moreover, topographic, geological maps were prepared, while climate data were collected from Baghdad meteorological station for the period 1996-2016.

Thirty four water samples were collected from different locations of Tigris River to cover the study reach of the river within two periods; January and April of 2019.

Locations of the samples were marked on the map by using GIS software (Figure-5). Each water sample was placed in a plastic bottle of $500 \mathrm{~mL}$ volume, with screw-on lid, where two samples were collected for each sample point; the first one for analyzing the major components, and the second for heavy metals analyses. All water samples were immediately covered with a tight screw-on lid, and perfectly labeled. No free headspace was left in the plastic bottle and it was ensured that the water sample in each bottle was in contact only with the plastic screw cap and plastic of the bottle. Table-3 illustrates the devices that were used during sampling procedure. WHO Guidelines of drinking water were compared to the ions concentration of water samples to find out if the water in the study area is suitable for human consumption or not.

Physical and chemical analyses of water samples were performed for the parameters of major ions (cations and anions), which are (Potassium $\left(\mathrm{K}^{+}\right)$, Sodium $\left(\mathrm{Na}^{+}\right)$, Cadmium $\left(\mathrm{Ca}^{+2}\right)$, Magnesium $\left(\mathrm{Mg}^{+2}\right)$, chloride $\left(\mathrm{Cl}^{-}\right)$, Sulfate $\left(\mathrm{SO}_{4}^{-2}\right)$, and Bicarbonate $\left(\mathrm{HCO}^{3-)}\right.$, as well as minor ions, which are nitrate $\left(\mathrm{NO}^{3-}\right.$ ) and Phosphate $\left(\mathrm{PO}_{4}^{-3}\right)$, along of the parameters of $\mathrm{pH}$, temperature, total dissolved solids (TDS), electrical conductivity (EC), total hardness (T.H.).

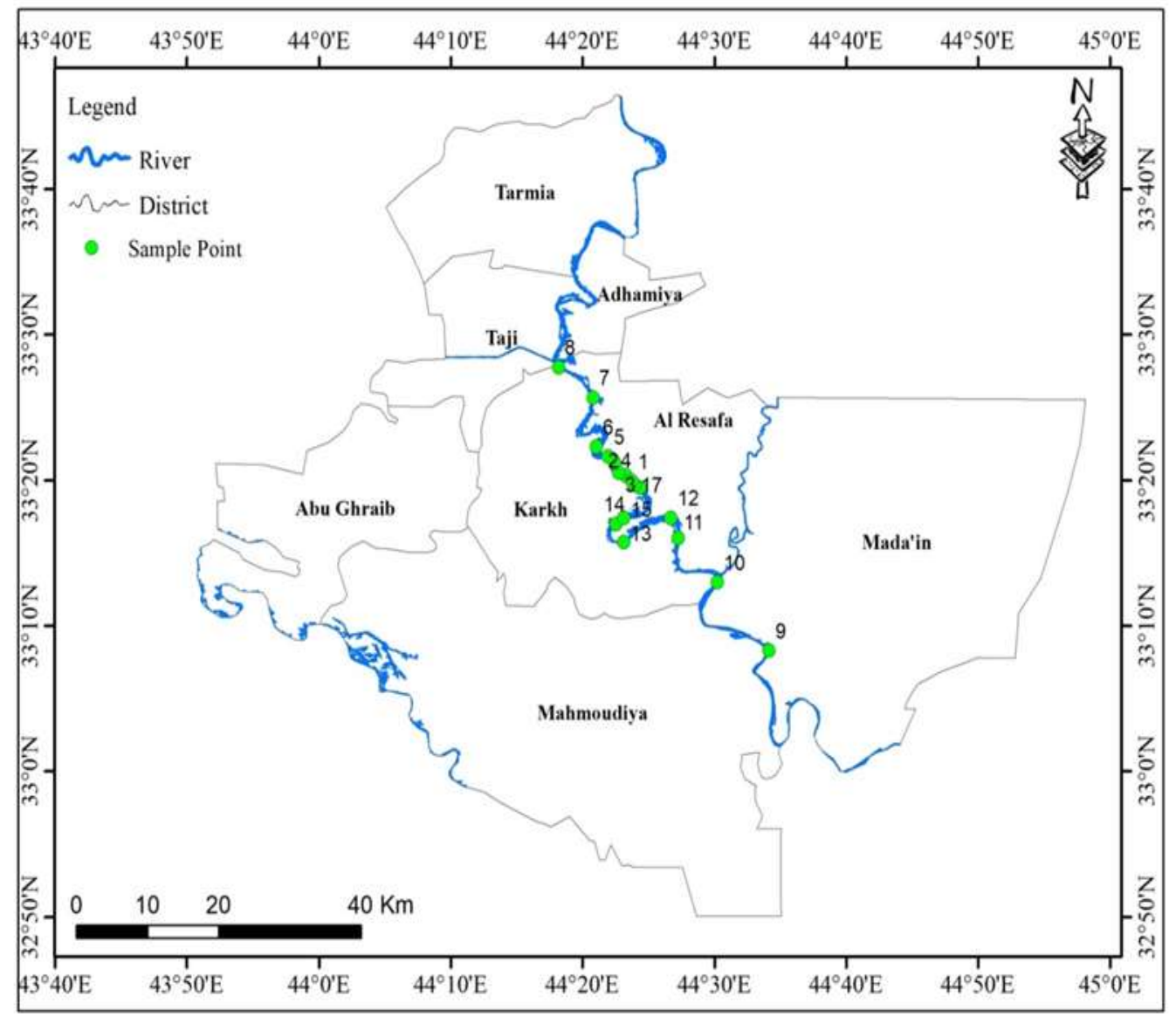

Figure 6-Sampling site location map. 
Table 2- Equipment used for sampling.

\begin{tabular}{|c|c|}
\hline Equipment & Purpose \\
\hline Global Positioning System (GPS) & To pinpoint geographic location of all samples \\
\hline Electrical conductivity meter (EC meter) & $\begin{array}{c}\text { Measure an electrical conductivity of water } \\
\text { samples }\end{array}$ \\
\hline Thermometer & $\begin{array}{c}\text { For measuring and indicating water samples } \\
\text { temperature }\left({ }^{\circ} \mathrm{C}\right)\end{array}$ \\
\hline $\begin{array}{c}\text { Potential of hydrogen } \\
(\mathbf{p H} \text { meter) }\end{array}$ & $\begin{array}{c}\text { A measure of acidity or alkalinity of water-soluble } \\
\text { substances }\end{array}$ \\
\hline
\end{tabular}

In order to find the accuracy of the laboratory test the following equations were used:

$(R D) \%=r C-r A / r C+r A x 100$

where:

$\mathrm{R} \mathrm{D}=$ Relative Difference

$\mathrm{rC}=$ summation of cations in epm units.

$\mathrm{rA}=$ summation of anions in epm units.

where:

$$
\mathrm{A} \%=100-\text { R.D } \%
$$

A\% = Accuracy

According to Stoodly, the results could be accepted for interpretation when A $\geq 95 \%$, and less accuracy would be acceptable with risk, but if the value is less than $90 \%$ then it is not accepted for interpretation [12]. For further insurance, a sample was duplicated in each test to increase the precision of the tests. According to Maxwell, precision represents the degree to which the repeated measurements show the same results. Therefore, the next equation was used [13]:

$$
\mathrm{P}=2 S / x \times 100
$$

where:

$\mathrm{P}=$ precision with level of confidence at $95 \%$

$\mathrm{S}=$ standard deviation

$x=$ arithmetic mean

According to Al-Janabi et al. the maximum acceptable limit for $\mathrm{p}$ is $\pm 20 \%$ [14].

To classify water and determine its type, two methods were used; the first is the hydrochemical (Kurolov) formula and the second is Piper diagram. The hydrochemical formula depends on the ratio of the main cations and anions, expressed as epm \%, that are arranged in a descending order and have more than $15 \%$ ratio of availability, according to Ivanovet al. The cations are usually located at the base while the anions are located above. In addition, TDS (mg/L) and $\mathrm{pH}$ values as in the following formula:

Anions epm\% decreasing order

$$
\text { TDS mg / L }
$$

Cations epm\% decreasing order

Piper diagrams, according to Fetter, allow both the anions and the cation to be represented on a single graph. These diagrams are also useful for visually describing the differences in major ions chemistry in water flow systems [16]. Piper diagram can be divided into seven types of water [17].

\section{Results and Discussion}

The climate data from Baghdad meteorological station for the period 1996-2016 are listed in Table-3. 
Table 3- Climatic data for Baghdad Meteorological Station (1996 - 2016)

\begin{tabular}{|c|c|c|c|c|c|c|c|}
\hline \multirow[t]{2}{*}{ Month } & \multirow{2}{*}{$\begin{array}{l}\text { Rainfall } \\
(\mathrm{mm})\end{array}$} & \multicolumn{2}{|c|}{$\begin{array}{c}\text { Mean temperature } \\
\left({ }^{\circ} \mathrm{C}\right)\end{array}$} & \multirow{2}{*}{$\begin{array}{l}\text { Evaporation } \\
\quad \text { (mm) }\end{array}$} & \multirow{2}{*}{$\begin{array}{c}\text { Relative } \\
\text { Humidity } \\
(\%)\end{array}$} & \multirow{2}{*}{$\begin{array}{l}\text { Wind } \\
\text { Speed } \\
(\mathrm{m} / \mathrm{sec})\end{array}$} & \multirow{2}{*}{$\begin{array}{l}\text { Sunshine } \\
\text { (h/day) }\end{array}$} \\
\hline & & Max. & Min. & & & & \\
\hline Oct. & 8.68 & 25.31 & 17 & 423.1 & 41.22 & 2.69 & 8 \\
\hline Nov. & 22.76 & 16.8 & 10.15 & 195.36 & 59.33 & 2.34 & 6.99 \\
\hline Dec. & 16.46 & 12 & 6.16 & 142.06 & 66.56 & 2.49 & 5.99 \\
\hline Jan. & 22.97 & 10.05 & 4.67 & 66.27 & 68.22 & 2.61 & 6.14 \\
\hline Feb. & 12.8 & 13.06 & 6.62 & 188.16 & 57.5 & 2.84 & 7.2 \\
\hline Mar. & 13.72 & 17.62 & 10.61 & 336.61 & 45.83 & 3.19 & 7.77 \\
\hline Apr. & 13.2 & 23.59 & 15.95 & 470.65 & 38.78 & 3.22 & 8.67 \\
\hline May. & 3.92 & 29.68 & 21.45 & 666.87 & 30.78 & 3.22 & 9.81 \\
\hline Jun. & 0 & 33.54 & 24.45 & 892.75 & 24.39 & 3.87 & 11.60 \\
\hline Jul. & 0 & 36.06 & 24.87 & 976.33 & 23.78 & 3.88 & 11.53 \\
\hline Aug. & 0 & 35.63 & 27.02 & 878.65 & 25.17 & 3.32 & 11.35 \\
\hline Sep. & 0.12 & 31.24 & 26.56 & 651.59 & 30.94 & 2.94 & 9.99 \\
\hline $\begin{array}{c}\text { Annual } \\
\text { mean }\end{array}$ & 114.63 & 23.71 & 16.29 & 490.7 & 42.7 & 3.05 & 105.04 \\
\hline
\end{tabular}

All the water samples have an acceptable accuracy as shown in Tables- $(4,5)$, and the precision of the tests of TDS and EC are also acceptable. Therefore, the result of the laboratory tests listed in Tables- $(6,7)$ can be used for interpretation.

Table 4-Accuracy of chemical analysis of January 2019 samples

\begin{tabular}{|c|c|c|}
\hline Sample number & RD \% & Accuracy \\
\hline 1 & 0.83 & 99.17 \\
\hline 2 & 1.21 & 98.79 \\
\hline 3 & 0.51 & 99.49 \\
\hline 4 & 0.84 & 99.16 \\
\hline 5 & 1.00 & 99.00 \\
\hline 6 & 0.23 & 99.77 \\
\hline 7 & 0.54 & 99.46 \\
\hline 8 & 0.22 & 99.78 \\
\hline 9 & 1.67 & 98.33 \\
\hline 10 & 0.25 & 99.75 \\
\hline 11 & 0.92 & 99.08 \\
\hline 12 & 0.31 & 99.69 \\
\hline 13 & 1.45 & 98.55 \\
\hline 14 & 1.77 & 98.23 \\
\hline 15 & 0.05 & 99.95 \\
\hline 16 & 0.88 & 99.12 \\
\hline 17 & 0.95 & 99.05 \\
\hline 18 & 0.97 & 99.03 \\
\hline
\end{tabular}


Table 5-Accuracy of chemical analysis of April 2019 samples

\begin{tabular}{|c|c|c|}
\hline Sample number & RD \% & Accuracy \\
\hline 1 & 2.07 & 97.93 \\
\hline 2 & 0.85 & 99.15 \\
\hline 3 & 1.17 & 98.83 \\
\hline 4 & 2.24 & 97.76 \\
\hline 5 & 1.54 & 98.46 \\
\hline 6 & 1.00 & 99.00 \\
\hline 7 & 0.86 & 99.14 \\
\hline 8 & -0.03 & 100.03 \\
\hline 9 & 0.08 & 99.92 \\
\hline 10 & 0.66 & 99.34 \\
\hline 11 & 4.53 & 95.47 \\
\hline 12 & 3.66 & 96.34 \\
\hline 13 & 1.50 & 98.50 \\
\hline 14 & 5.18 & 94.82 \\
\hline 15 & 1.26 & 98.74 \\
\hline 16 & 2.99 & 97.01 \\
\hline 17 & 3.68 & 96.32 \\
\hline 18 & 1.83 & 98.17 \\
\hline
\end{tabular}


Table 6-Concentration of major elements in water samples of January 2019

\begin{tabular}{|c|c|c|c|c|c|c|c|c|c|}
\hline \multirow{3}{*}{$\begin{array}{c}\text { Sample } \\
\text { No. }\end{array}$} & \multicolumn{4}{|c|}{ Cations } & \multicolumn{3}{|c|}{ Anions } & \multirow{2}{*}{ TDS } & \multirow{3}{*}{$\begin{array}{c}\text { EC } \\
(\mu \mathrm{S} / \mathrm{cm})\end{array}$} \\
\hline & $\mathrm{Ca}^{2+}$ & $\mathbf{M g}^{2+}$ & $\mathrm{Na}^{+}$ & $\mathbf{K}^{+}$ & $\mathrm{Cl}^{-}$ & $\mathrm{SO}_{4}{ }^{-2}$ & $\mathrm{HCO}_{3}^{-}$ & & \\
\hline & \multicolumn{8}{|c|}{$(\mathbf{p p m})$} & \\
\hline 1 & 58 & 23 & 49 & 0.6 & 95 & 146 & 67.50 & 438 & 876 \\
\hline 2 & 61 & 24 & 51 & 0.7 & 93 & 152 & 77.98 & 460 & 919 \\
\hline 3 & 65 & 23 & 50 & 0.9 & 95 & 150 & 87.98 & 472 & 944 \\
\hline 4 & 58 & 21 & 53 & 0.6 & 93 & 151 & 64.08 & 440 & 881 \\
\hline 5 & 57 & 22 & 51 & 2.8 & 92 & 148 & 67.98 & 441 & 881 \\
\hline 6 & 59 & 23 & 50 & 2.4 & 93 & 150 & 77.98 & 455 & 910 \\
\hline 7 & 56 & 17 & 63 & 0.5 & 80 & 159 & 78.67 & 453 & 906 \\
\hline 8 & 59 & 19 & 70 & 0.4 & 74 & 166 & 120.00 & 508 & 1015 \\
\hline 9 & 55 & 18 & 66 & 0.4 & 77 & 163 & 87.98 & 467 & 933 \\
\hline 10 & 42 & 25 & 64 & 0.4 & 83 & 163 & 68.99 & 446 & 891 \\
\hline 11 & 63 & 25 & 56 & 3.3 & 102 & 157 & 86.31 & 493 & 985 \\
\hline 12 & 67 & 26 & 57 & 0.3 & 125 & 156 & 68.25 & 500 & 999 \\
\hline 13 & 64 & 28 & 51 & 0.3 & 106 & 161 & 68.59 & 479 & 958 \\
\hline 14 & 74 & 24 & 56 & 0.7 & 96 & 154 & 116.35 & 521 & 1043 \\
\hline 15 & 66 & 25 & 55 & 1.6 & 69 & 153 & 160.00 & 530 & 1059 \\
\hline 16 & 62 & 26 & 65 & 2.0 & 101 & 162 & 108.99 & 528 & 1055 \\
\hline 17 & 66 & 26 & 56 & 3.3 & 81 & 154 & 140.81 & 527 & 1055 \\
\hline 18 & 68 & 26 & 56 & 2.3 & 63 & 134 & 201.01 & 550 & 1100 \\
\hline $\begin{array}{l}\text { WHO } \\
(2018)\end{array}$ & 200 & 150 & 100 & 12 & 250 & 250 & - & 1000 & - \\
\hline
\end{tabular}


Table 7-Concentration of major elements in water samples of April 2019

\begin{tabular}{|c|c|c|c|c|c|c|c|c|c|}
\hline \multirow{3}{*}{$\begin{array}{c}\text { Sample } \\
\text { No. }\end{array}$} & \multicolumn{4}{|c|}{ Cations } & \multicolumn{3}{|c|}{ Anions } & \multirow{2}{*}{ TDS } & \multirow{2}{*}{ EC } \\
\hline & $\mathrm{Ca}^{2+}$ & $\mathbf{M g}^{2+}$ & $\mathrm{Na}^{+}$ & $\mathbf{K}^{+}$ & $\mathrm{Cl}^{-}$ & $\mathrm{SO}_{4}{ }^{-2}$ & $\mathrm{HCO}_{3}^{-}$ & & \\
\hline & \multicolumn{8}{|c|}{$(\mathbf{p p m})$} & $(\boldsymbol{\mu S} / \mathbf{c m})$ \\
\hline 1 & 62 & 37 & 72 & 5 & 144 & 225 & 30 & 610 & 886 \\
\hline 2 & 58 & 34 & 65 & 3.6 & 136 & 192 & 26 & 593 & 878 \\
\hline 3 & 59 & 34 & 64 & 3.5 & 135 & 193 & 25 & 592 & 878 \\
\hline 4 & 63 & 38 & 74 & 6 & 147 & 228 & 32 & 615 & 888 \\
\hline 5 & 55 & 32 & 60 & 2 & 131 & 193 & 24 & 575 & 870 \\
\hline 6 & 57 & 33 & 64 & 3.4 & 135 & 190 & 25 & 584 & 876 \\
\hline 7 & 75 & 42 & 82 & 8 & 170 & 259 & 48 & 730 & 1065 \\
\hline 8 & 63 & 37 & 73 & 5.5 & 145 & 227 & 32 & 616 & 888 \\
\hline 9 & 45 & 24 & 70 & 4 & 131 & 137 & 18 & 460 & 693 \\
\hline 10 & 40 & 20 & 60 & 2.1 & 106 & 129 & 16 & 400 & 596 \\
\hline 11 & 67 & 40 & 80 & 7 & 156 & 240 & 36 & 640 & 906 \\
\hline 12 & 66 & 40 & 78 & 7 & 155 & 238 & 35 & 638 & 905 \\
\hline 13 & 76 & 46 & 89 & 7.8 & 165 & 250 & 39 & 674 & 918 \\
\hline 14 & 72 & 43 & 84 & 7.5 & 160 & 244 & 37 & 660 & 912 \\
\hline 15 & 75 & 45 & 87 & 7.7 & 164 & 249 & 38 & 675 & 916 \\
\hline 16 & 80 & 48 & 96 & 11 & 188 & 288 & 57 & 772 & 1101 \\
\hline 17 & 52 & 30 & 85 & 1.2 & 195 & 140 & 22 & 570 & 863 \\
\hline 18 & 58 & 33 & 64 & 3.4 & 135 & 190 & 25 & 585 & 876 \\
\hline $\begin{array}{l}\text { WHO } \\
\text { (2018) }\end{array}$ & 200 & 150 & 100 & 12 & 250 & 250 & - & 1000 & - \\
\hline
\end{tabular}

Water classification

The classification of water samples using hydrochemical formula concluded that there are three water types, ordered from more to less common, in each period, as follows:

For January 1- $\mathrm{Ca} \mathrm{Na} \mathrm{Mg}-\mathrm{SO}_{4} \mathrm{Cl} \mathrm{HCO}_{3}$

2- $\mathrm{Na} \mathrm{Ca} \mathrm{Mg}-\mathrm{SO}_{4} \mathrm{Cl} \mathrm{HCO}$

3- $\mathrm{Ca} \mathrm{Na} \mathrm{Mg}-\mathrm{SO}_{4} \mathrm{HCO}_{3} \mathrm{Cl}$

4- $\mathrm{Ca} \mathrm{Na} \mathrm{Mg}-\mathrm{SO}_{4} \mathrm{Cl}$

And for April: 1- $\mathrm{NaCa} \mathrm{Mg}-\mathrm{SO}_{4} \mathrm{Cl}$

2- $\mathrm{Ca} \mathrm{Na} \mathrm{Mg}-\mathrm{SO}_{4} \mathrm{Cl}$

3- $\mathrm{Na} \mathrm{Ca} \mathrm{Mg}-\mathrm{Cl} \mathrm{SO} 4$

As for Piper diagrams, they showed that all the water samples fall in the field of alkaline earth, in which $\left(\mathrm{Ca}^{2+}\right.$ and $\mathrm{Mg}^{2+}$ are dominant with increased $\mathrm{Na}^{+}$and prevailing sulfate, as shown in Figures$(8,7)$. 
Piper Diagram
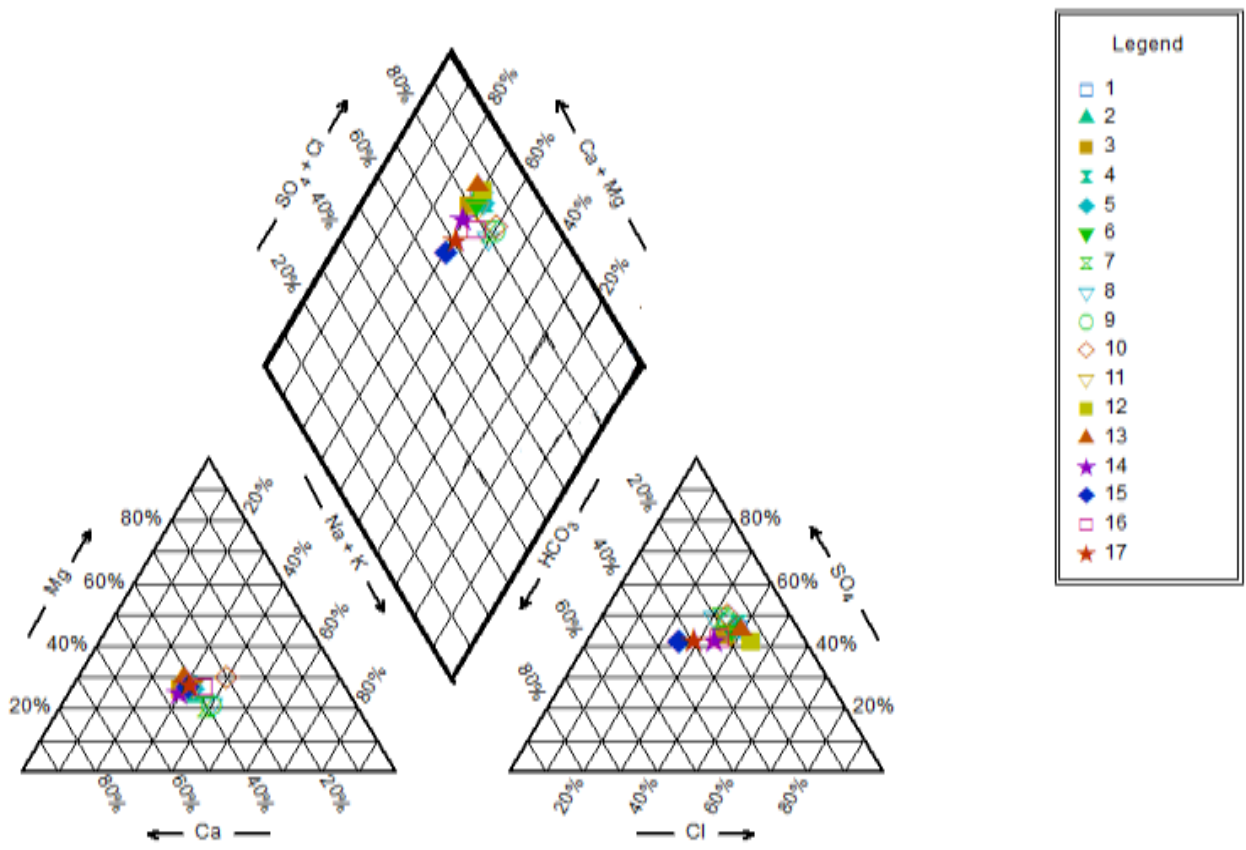

Figure 7-Piper diagram for water samples in January 2019.

Piper Diagram
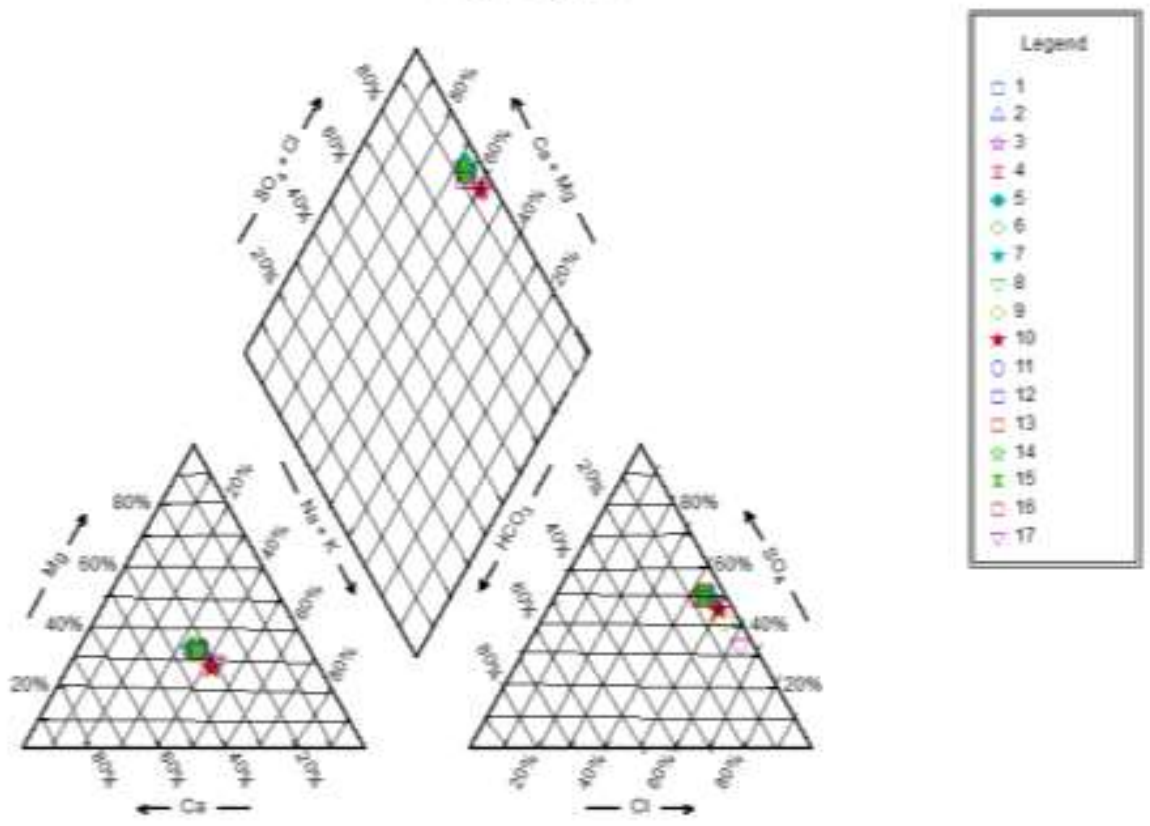

Figure 8-Piper diagram for water samples in April 2019.

The dominating $\mathrm{Ca}^{2+}$ and $\mathrm{Mg}^{2+}$ may cause water hardness and the high $\mathrm{Na}^{+}$concentration may be due to domestic and factories waste, while the dominating $\mathrm{SO}_{4}$ might be caused by scales build up on pipes and stains for clothes.

\section{Conclusions}

Based on the results of hydrochemical tests and WHO (2018) guidelines[18], it was found that:

1- TDS and EC values for all water samples are within the WHO limits of drinking water.

2- Calcium concentration in all samples was acceptable, with an average of 61.88 and a range between 40 to $80 \mathrm{ppm}$ for both seasons.

3- Magnesium concentration was acceptable in all samples, and it ranged from 17 to 48 ppm with an 
average of $32 \mathrm{ppm}$.

4- Sodium concentration in all samples was acceptable. with the average and it ranged between

5- Potassium concertation was acceptable in all samples and it ranged from 0.3 to $8 \mathrm{ppm}$ with a mean of $4.15 \mathrm{ppm}$.

6- The concentrations of most ions in the second season were higher than those in the first season, which could be due to high rainfall rate with the resulting washing of chemical substances to the river from soil or storm drainage.

The most common water type in January 2019 was $\mathrm{Ca} \mathrm{Na} \mathrm{Mg}-\mathrm{SO}_{4} \mathrm{Cl} \mathrm{HCO}_{3}$ while that in April $\mathrm{Na} \mathrm{Ca}$ $\mathrm{Mg}-\mathrm{SO}_{4} \mathrm{Cl}$.

\section{References}

1. National Geographic. 2019. Tigris River. Available at https:// www. nationalgeographic.org lencyclopedia/tigris-river/ Access on 19 September, 2019.

2. Briggs, D., 2003. Environmental pollution and the global burden of disease. British Medical Bulletin, 68(1): 1-24, https://doi.org/10.1093/bmb/ldg019. Accessed on 14/07/18.

3. Ali S. M. 2012. Hydrological environmental assessment of Baghdad area, Ph. D. Thesis, university of Baghdad.

4. Alazawii L. H., Nashaat M. R. and Muftin F. Sh. 2018. Assessing the Effects of Al- Rasheed Electrical Power Plant on the Quality of Tigris River, Southern of Baghdad by Canadian Water Quality Index (CCME WQI). Iraqi Journal of Science, 2018, 59(3A): 1162-1168.

5. Awadh S. M. and Khalid S. A. 2019. Assessment of Magnetite Polishing by Using Tigris River Stream Sediments in Baghdad: An Ore Microscopy Application. Iraqi Journal of Science, 2019, 60(2): 330-340.

6. Saud, Q. J. 2014. Effects of Selected Contaminants on the Physical, Chemical, and Geotechnical Properties of Aquifer Solid. Ph.D. Thesis, University of Missouri-Kansas City. Available at: https://hdl.handle.net/10355/45614. Access on 14 May 2019.

7. Encyclopædia Britannica Online, 2011. Baghdad. http://www.newworldencyclopedia.org/ entry/Baghdad\#cite note-largestcities-1 Accesses on April 2019.

8. Thoughtco, Co. 2011. Largest Cities through History Geography. Accesses on April 2019. https://www.thoughtco.com/largest-cities-throughout-history-4068071

9. Jassim, S. Z. and Goff, J. C. 2006. Geology of Iraq, Published by Dolin, Pragh and Moravian Mueseum, Brno, p. 302

10. Deikran, D.B. and Yacoub, S.Y. 1993. Series of geological maps of Iraq scale 1:250000, Baghdad Quadrangle (NI-38-10). GEOSURV, int. rep. no. 2255.

11. Sissakian, V.K. and Fouad, S.F. 2016. Geological Map of Iraq, 4th edit. Scale 1:1000000. Iraq Geological Survey, GEOSURV, Baghdad, Iraq.

12. Stoodly, K.D., Lewis, T. and Stantion, C.L. 1980. Applied Statistical Techniques, John Wiley and Sons, London.

13. Maxwell, J. A. 1968. Rock and Minerals Analysis, John Wiley and Sons, NewYork, p. 584

14. Al-Janabi, A.Y., Al-Saadi, N. A., Zainal, Y. M., Al- Bassam, K. S. and Al-Delaimy, M. R. 1992. Work procedures of the S. E of Geological Survey and Mining, State Establishment of Geological Survey and Mining (GEOSURV), part 21, No. 2002.

15. Ivanov V. V. 1968. The main genetic type of the Earth crust mineral water and their distribution in USSR. Inter. Geol. Cong. Of 23rd sessions, Czechoslovakia, 12, 33p.

16. Fetter C.W. 2001. Applied Hydrogeology, (3rded.). Prentice Hall, Inc., Englewood Cliffs, New Jersey, 691p.

17. Piper, A. M. 1944; A graphic procedures in geochemical interpretation of water analysis. Trans. Am. Geophys. Union, 25: $914-923$.

18. WHO (world health organization), 2018. A global overview of national regulations and standards for drinking-water quality. Licence: CC BY-NC-SA 3.0 IGO. Available at: http://apps.who.int/iris/bitstream/handle/10665/272345/9789241513760-eng.pdf?ua=1 Access on 14 July 2. 